\title{
使い捨て鼓膜電極を用いた蝸電図検査法に関する研究
}

\author{
宮䗁医科大学医学部耳㸶喉科学教空（主任：森渵 保教授) \\ 松浦宏司, 東野折也, 原 由起代, 植木義裕 \\ 牛迫明, 渵保
}

\section{TYMPANIC ELECTROCOCHLEOGRAPHY WITH DISPOSABLE ELECTRODE}

\author{
KOJI MATSUURA, M.D. TETSUYA TONO, M.I., YUKIYO HARA, M.D., YOSHIHIRO UEKI, M.D. \\ YASUAKI USHISAKO, M.D. and TAMOTSU MORIMITSU, M.D.
}

Department of Otolaryngology, Miyazaki Medical College, Miyazaki

\begin{abstract}
Extratympanic recording of electrocochleography (ECochG) has played an important role in the differential diagnosis of inner ear diseases. We used a special electrode, which was wrapped in a cotton ball at the tip and covered with a silicon sheath over the entire length, and recorded ECochG from the tympanic membrane (tympanic ECochG). Our method was found to be more convenient and less traumatic than recording with an ear-canal electrode. Tympanic ECochG records from 10 normal volunteers showed no influence of iontophoretic anesthesia on the tympanic membrane. The effects on the conductive hearing mechanism were negligible. The input-output curve of the action potential (AP) by click stimuli was fairly stable and comparable to that obtained with transtympanic recording. We performed tympanic ECochG in patients with Meniere's disease or other sensory hearing loss, and compared the amplitude ratios of the summating potential (SP) and AP (SP/AP ratio) with those in normal hearing subjects. The SP/AP ratios in patients with Meniere's disease were significantly increased, an observation consistent with the results of other studies. The SP/AP ratio was also elevated in patients with autoimmune sensory hearing loss or perilymphatic fistula. Based on the results of the present study, we speculate that it is possible to diagnose an inner ear disorder by comparing the tympanic ECochG findings with not only records from normal subjects, but also the contralateral record of tympanic ECochG from the same subject. We conclude that tympanic ECochG using disposable electrodes can provide useful information on inner ear function, because of its convenience, non-invasiveness and safety in clinical use. We found tympanic ECochG to be useful in the glycerol dehydration test and for monitoring inner ear function during acoustic neurinoma surgery.
\end{abstract}

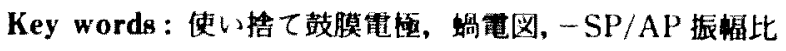

A $99-1016-23022$

\section{はじめに}

蚂紫图 electrocochleogram (EcochG) は螖4を発生 源とする䉓気反店記録図の略称加油来しており，各

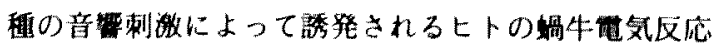
を示す。これは他筧的な内耳機能愉在法の一つとして， その臨休的な有用性を商めつつある
内耳により近くなればそれだけ良好な条件での記録が 可能となる理由で鼓室内㮩运法が広く用いられてき た。しかしながらこの方法は豉室内榷極の㨀入に当 たって攱脕切開，あるいは针电極そのものによる穿刺 が不可欠であるため, 被験者の承諾が得られない場合 が少なくない。また特に良聴耳の模査に当たってはよ 
り非侵襲的な方法が求められる。これに対し, 鼓室外 電極による螖電図検查は豉膜切開が要らない利点があ り, 臨床の場て用いられる例が増えつつある. 今回我々 は, 最近欧米の数施設て行われている“Tympanic electrocochleography (鼓膜蝸電図法)” ৬ー7) の実用性 を検討するに当たり，使い捨て可能な鼓膜電極を工夫 した. 正常聴力例について基礎的な研究を行い，鼓膜 承極螖電図法の有用性を確認したので報告する、また 感音難聴のみられる症例を対象として, 従来の方法と の比較・検討を行ったので報告する.

\section{器材と手技}

\section{1. 鼓膜電極の作製}

直径 $0.3 \mathrm{~mm}$ の銀線を長さ約 $15 \mathrm{~cm}$ のシリコン チュープ内に入れ、チューブから出ている部分のコー ティングを除去した. 鼓膜に接する一端はルーブ状に 曲げ, 綿花を小さく巻き付けてボール状もしくは滴状 にし、この部分に通電性ぺーストを浸して鼓膜電極と した.この際，一般の血電極用のペーストは半固形で 粘性が高すぎるため,心電図検査で用いられる粘性の 低い液状のもの（日本光電社製 Cardiocream）を使用 した. 図 1 上段に鼓膜電極の全体像を示した。検査終 了後には, 電極部分の綿花を完全に取り除いて, 消毒 液を漫したガーゼま沈はカット綿で銀線部分ならびに チューブを消毒し，次の検査には先端部分を新たに作 製した。

\section{2. 電極設置法}

鼓膜表面の麻醉としてイオン浸透麻酔器を用い, $4 \%$ \% シロカンとエピネフリン混合液にて 9 〜2分 間の鼓膜麻酔を行った。鎮痛詴や鎮静郕の投与は行わ ない．電極設置に当たっては手術用䫈微鏡下に鼓膜を 明視下に置き，先端が滕付近に当たるようにする。設 置した電極は米国 Cabot 社製 EAR LINK ${ }^{\circledR}$ を外耳道 に插入することによってシリコンチューフこと外耳道 壁に压迫・固定される。接着刘や特別な器具は用いな かった. EAR LINK ${ }^{\varepsilon} の$ 先端部分は外耳道の個人差に 合わせられるように, 直径 $12 \mathrm{~mm}$ と $6 \mathrm{~mm}$ の異なる 2 種類が用意されている. 不関電極は検査側の耳介後部 皮成に, 接地電函は前額部正中に置いた。

\section{3. 音刺激}

Cabot 社製のEAR TONE $3 A^{\circledR}$ から発生させた Click 音を用いた。脣さ $30 \mathrm{~cm}$ のチューブを介して, 先 に外耳道に挿入された EAR LINK ${ }^{\circledR}$ に接続し, 閉鎖系 として鼓膜表面より約 $2 \mathrm{~cm}$ の距離をおいた。 EAR
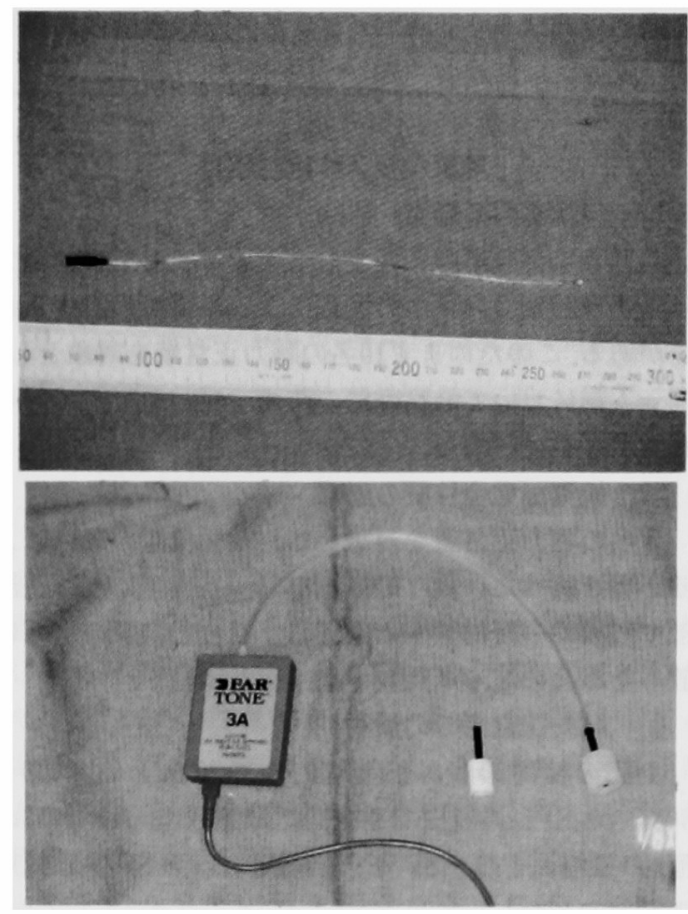

图 1 鼓膜電極 (上段), おょび EAR TONE $3 A^{\circledR}$ と EAR LINK ${ }^{\circledR}$ (下 段）の全体像

電極先端は, シリコンチューブよ りでている銀線のコーティングを 除去し, 鼓膜に接する一端はルー プ上に曲げて綿球で覆っている。 設定された音は, 下段写真左側の 箱状のスピーカーEAR TONE $3 A^{\circledast \triangleright}$ よ，右側のEAR LINK ${ }^{\circledR}$ 介して耳内に届く.

TONE $3 A^{\oplus}$ と接続された EAR LINK ${ }^{\circledR} の$ 全体写真を 図 1 下段に示した。刺激音の設定には日本電気三栄社 製誘発電位測定装置 7S12 を使用した。音圧は被験耳 の外耳道入口部にコンデンサーマイクロフォン（B＆ K 社 Probe Microphone type 4182)を設置して, 周波 数解析装置( B \& K 社 Real-time Frequency Analyzer type 2143)でモターしたものを基準とし, peak equivalent SPL (dB pe SPL)によって表示した。

4. 測定

シールドされた防音室内で被験者は仰臥位とし測定 を行った。測定開始前に, 各電極間抵抗が $20 \mathrm{k} \Omega$ 末満て あることを記録装置の抵抗郡により確楒した，加算回 数500回, 刺軠間隔 $9.5 \mathrm{~Hz}$, 解析時間 $10 \mathrm{ms,} \mathrm{フィル夕}$ 
の通過带域は $50 \sim 3000 \mathrm{~Hz}$ とした．記録波形の加算平 均・記録には前述の7S12 を用いた。

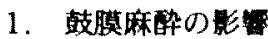

\section{对奥ならしに梌时项目}

リドカインを用いるイオントフォレーゼ法について

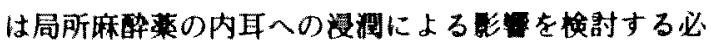
要がある。このためまず10名の聴力正常者を対象とし， 同一人物において豉膜麻酔の前後て湘定を行って得ら れた波形を模封した。

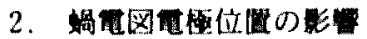

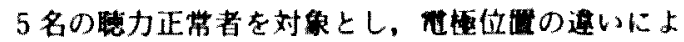

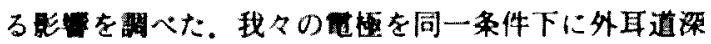

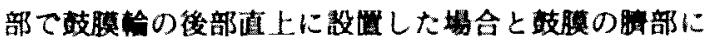

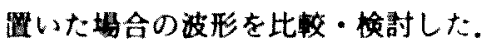

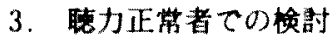

上記の㛟討の後，正常猡力者老对象とし，100

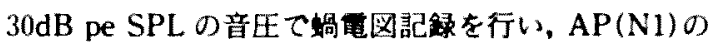

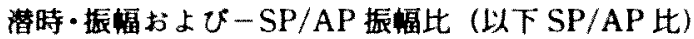
の測定をした。

\section{4. 䧐断的有用性の模乾}

16〜75歳まての感音難德症例を村象として梌討を 行った.内訳はメニエール病と診断された症例11と。

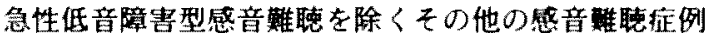
11例の咭22例である。螖電图は $90 \mathrm{~dB}$ pe SPL の音压て $\mathrm{AP}(\mathrm{N} 1)$ と一SP の振幅を测定した.正常㯖力者との比 较とともに、特に内リンパ水期で特的とされる $\mathrm{SP} /$ AP比の佣大について，メ二エール病とその他の感音

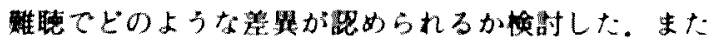

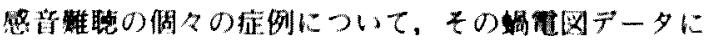

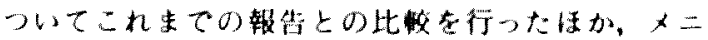

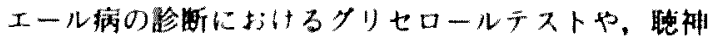
経䏸場の術中モニタリンタに成する有用性についても 検嗼した。

\section{䊅果}

1. 豉膜晽醉の㩆

同一被験者について，イオントフォレーゼによる跂 膜麻醉の前後で行った螖暼图の典型例を图 2 に示し た．上段は麻醉前，下段は麻酔後の記録である。刺物 音压仕上から順に70，80，90，100dB pe SPLで，矢

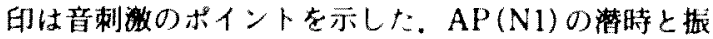
幅について，10人での测定結果を表1に示した（N=

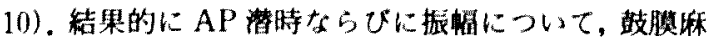

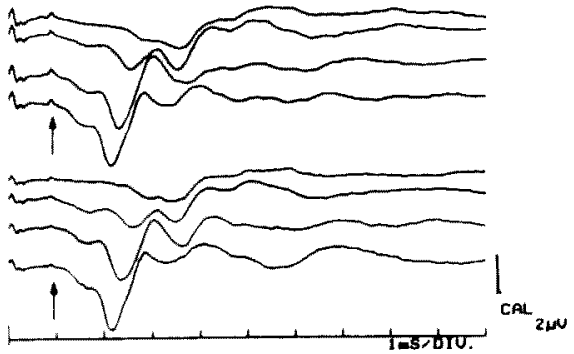

因 2 鼓膜麻醉前後の波形 上段は豉膜柘醉前，下段は鼓膜柘醉 後。それそれ下方から順に100，90， $80,70 \mathrm{~dB}$ pe SPL. 矢印：音刺粉。

衰 1 鼓湟麻酔前後の $\mathrm{AP}(\mathrm{N} 1)$ の潜時と 振幅についての湖定結果

\begin{tabular}{|c|c|c|c|}
\hline & $\mathrm{dB}$ & 潜時 (msec) & 振幅 $(\mu \mathrm{V})$ \\
\hline \multirow{4}{*}{$\begin{array}{l}\text { 麻 } \\
\text { 酔 } \\
\text { 前 }\end{array}$} & 70 & $2.18 \pm 0.28$ & $1.60 \pm 0.65$ \\
\hline & 80 & $1.68 \pm 0.16$ & $2.60 \pm 1.45$ \\
\hline & 90 & $1.54 \pm 0.07$ & $3.30 \pm 1.28$ \\
\hline & 100 & $1.38 \pm 0.13$ & $3.93 \pm 1.11$ \\
\hline \multirow{4}{*}{$\begin{array}{l}\text { 麻 } \\
\text { 醉 } \\
\text { 後 }\end{array}$} & 70 & $2.14 \pm 0.39$ & $1.79 \pm 0.98$ \\
\hline & 80 & $1.72 \pm 0.14$ & $2.12 \pm 1.35$ \\
\hline & 90 & $1.52 \pm 0.08$ & $3.45 \pm 1.18$ \\
\hline & 100 & $1.32 \pm 0.05$ & $4.00 \pm 1.35$ \\
\hline
\end{tabular}

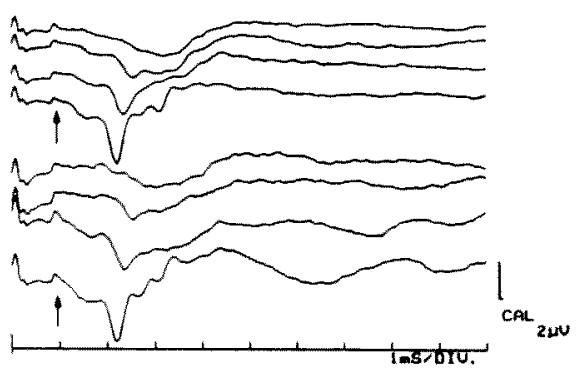

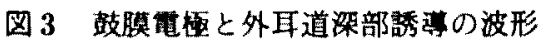
上段は豉膜電極，下段は同し電極で の外耳道唀票。それそれ下方から順 $に 100,90,80,70 \mathrm{~dB}$ pe SPL. 矢印: 音制激.

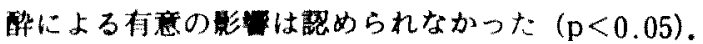

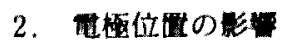

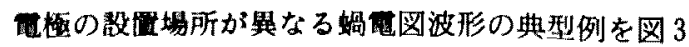


表 2 電極位䁬の違いによる AP(N1) の 潜時と振幅についての测定結果

\begin{tabular}{|c|c|c|c|}
\hline & $\mathrm{dB}$ & 潜時 (msec) & 振幅 $(\mu \mathrm{V})$ \\
\hline \multirow{4}{*}{$\begin{array}{l}\text { 鼓 } \\
\text { 膜 } \\
\text { 殽 } \\
\text { 部 }\end{array}$} & 70 & $2.46 \pm 0.32$ & $1.80 \pm 0.65$ \\
\hline & 80 & $1.72 \pm 0.16$ & $2.29 \pm 1.08$ \\
\hline & 90 & $1.48 \pm 0.09$ & $3.53 \pm 1.45$ \\
\hline & 100 & $1.32 \pm 0.07$ & $4.27 \pm 1.28$ \\
\hline \multirow{4}{*}{$\begin{array}{l}\text { 外 } \\
\text { 耳 } \\
\text { 道 }\end{array}$} & 70 & $1.84 \pm 0.45$ & $2.00 \pm 0.76$ \\
\hline & 80 & $1.6 t=0.37$ & $2.50 \pm 0.96$ \\
\hline & 90 & $1.50 \pm 0.41$ & $4.80 \pm 1.33$ \\
\hline & 100 & $1.38 \pm 0.14$ & $5.80 \pm 1.44$ \\
\hline
\end{tabular}

a
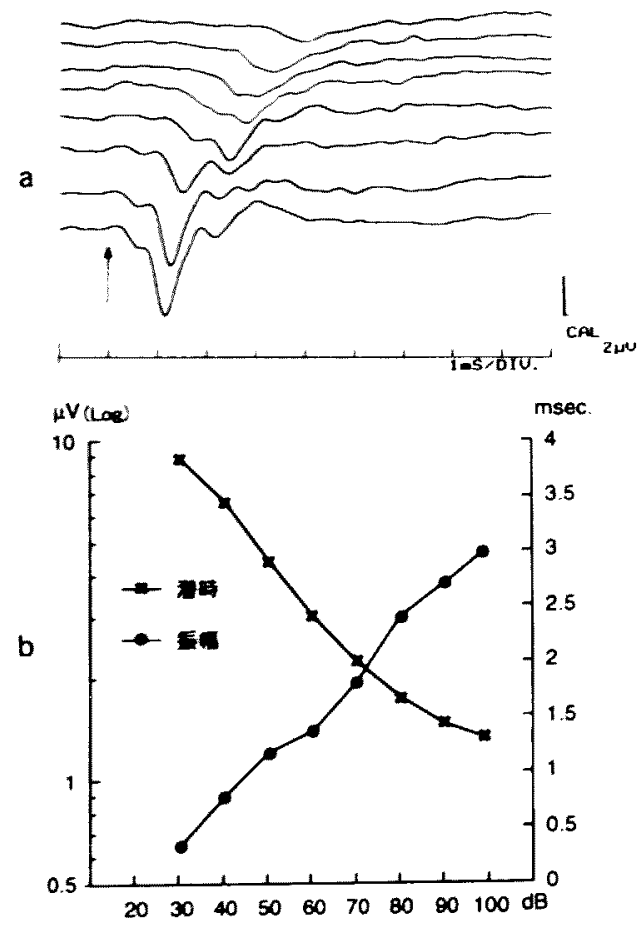

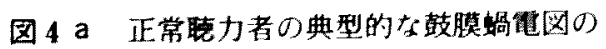
原波形

下方より碩に100〜30dB pe SPL. 矢印: 音刺䑤。

b 正常聴力ボランティア10名より得ら 几た AP (N1)について平均潜時, および振幅をプロットした入出力曲 線.
表 3 正常聴力者と鱆聴のある症例の SP/AP 比の比較

\begin{tabular}{|c|c|c|c|}
\hline & 最小值 & 最大值 & 平均 $\pm \mathrm{SD}$ \\
\hline $\begin{array}{c}\text { 正常聴力者 } \\
(\mathrm{n}=10)\end{array}$ & 0.14 & 0.36 & $0.26 \pm 0.08$ \\
\hline $\begin{array}{c}\text { × } \\
(\mathrm{n}=11)\end{array}$ & 0.21 & 0.73 & $0.40 \pm 0.17$ \\
\hline $\begin{array}{c}\text { その他の感音難聴 } \\
(\mathrm{n}=11)\end{array}$ & 0.18 & 0.60 & $0.35 \pm 0.12$ \\
\hline
\end{tabular}

に示した。上段は电極を我々が通常行っているように

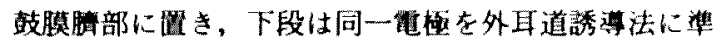
じて外耳道深部の鼓膜䖝に接した位诲に活き記録し た.この際外耳道誘遷法においてし, 前処消としてイ オントフォレーゼ麻酔を行った。それぞれ刺激音在は 上から順に $70,80,90,100 \mathrm{~dB}$ pe SPLで，矢印は音 刺激のポイントを示した。 $\mathrm{AP}(\mathrm{N} 1)$ の潜時と振幅につ いてその 5 名での湘定結果を表 2 に示した $(p<$ 0.05).鼓膜の腤部に設置した場合と, 外耳道染部の沞 誘導法において, $\mathrm{AP}(\mathrm{Nl})$ の)振幅については若干外耳 道誘導の方が大きい傾向にあったが，潜時と振幅につ いてそれぞれ有意な差は認めなかった（ $p<0.05 ）$ 。

\section{3. 聴力正常者での㛟討}

正常者を用いた鼓膜媧眥図は再現性の高い AP, SP の反応波形を得ることができた。图4 aは記録された 舆型的な原波形である。知は㚙刺敏のボイントで， 音压は级下段が $100 \mathrm{~dB}$ pe SPLで上万に $10 \mathrm{~dB}$ ステッ プで弱くなっている. 図4 b は嚼力正常者10名を被检

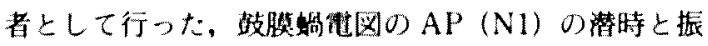
幅（刘数倠）について平均をプロットし，音在に対す る入出力曲線にしたものである. AP(N1)は $100 \mathrm{~dB}$ pe SPL で潜時平均 $1.34 \mathrm{msec} \pm 0.05$, 振幅平均 $4.00 \mu \mathrm{V} \pm 1.3,90 \mathrm{~dB}$ pe SPL ては潜時平均 $1.48 \mathrm{msec} . \pm 0.08$, 振幅平均 $3.33 \mu \mathrm{V} \pm 1.43$ でった。 また SP/AP比の平均は $100 \mathrm{~dB}$ pe SPL で0.26土 $0.08,90 \mathrm{~dB}$ pe SPL で0.28士0.05であった。

\section{4. 彭断的有用性の倹郡}

表 3 に示すように，22例の感音難德症例のうち，そ

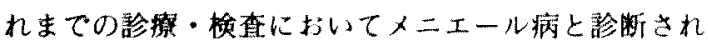
た11例の SP/AP 比法平均 $0.40 \pm 0.17$ ，飞の他の感音 難聴の SP/AP 比は平均 $0.35 \pm 0.12$ てあった。前者の $\mathrm{SP} / \mathrm{AP}$ 比は正常聴力者に比較して有意に大きく $(\mathrm{p}<$ 


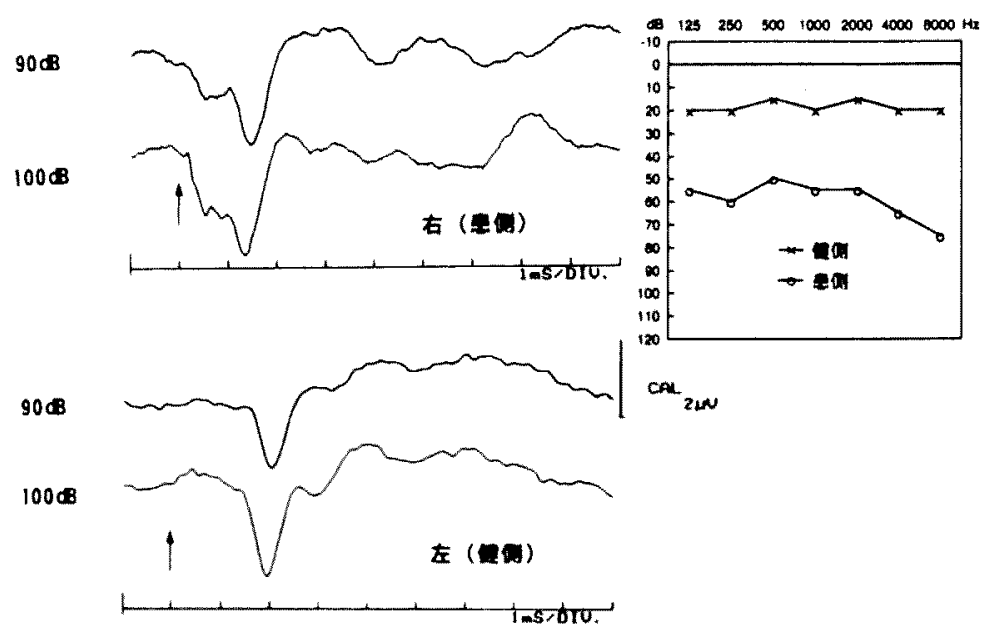

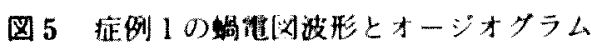

SP/AP 比は 100dB pe SPL C思側が0.68，健側が0.16.

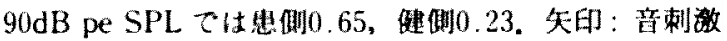

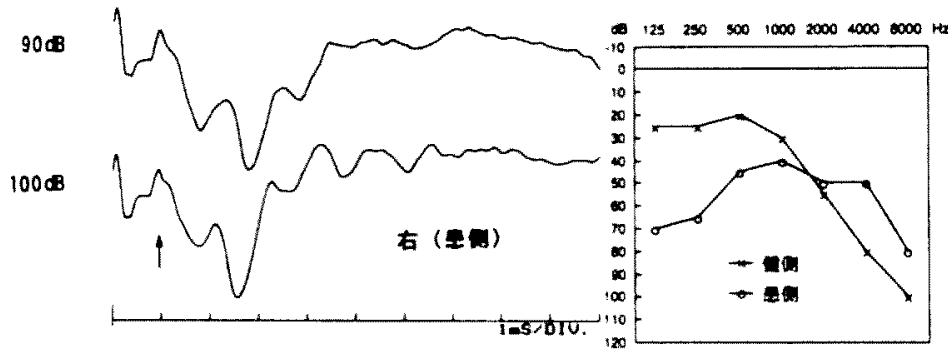

900

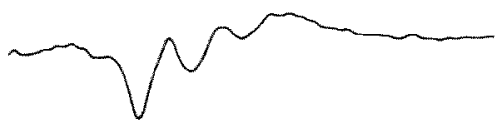

$100 \mathrm{~d}$

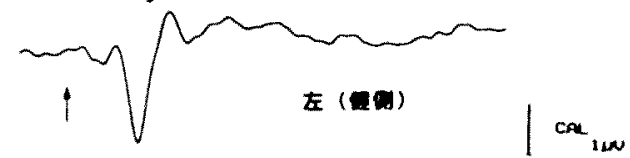

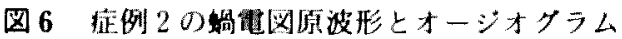
$\mathrm{SP} / \mathrm{AP}$ 比は 100dB pe SPL で急側が0.59，健側が0.15.

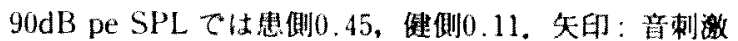

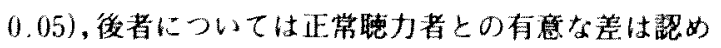

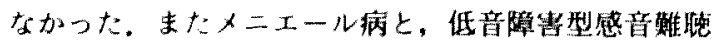
を除くその他の感音難㯖提例との間にSP/AP比につ

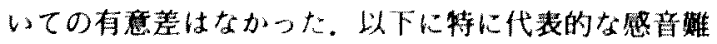

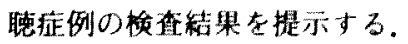

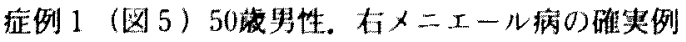
で，当初は低音域のみの橞カレベルの悬化てあった。
経過中增態と経块を編り返し，水平型の中等度感音難

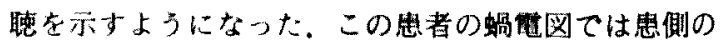
$\mathrm{SP} / \mathrm{AP}$ 比が $90 \mathrm{~dB}$ pe SPL 20.65 と正常婹力者の平均 $0.26 に$ 比へて有意に大きい。布た健側についても同粎

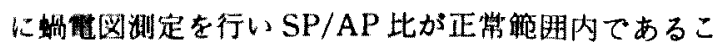
とを確㻊した。

症例 2 (図 6) 58藏男性. 右自己免投性感音難聴疑 


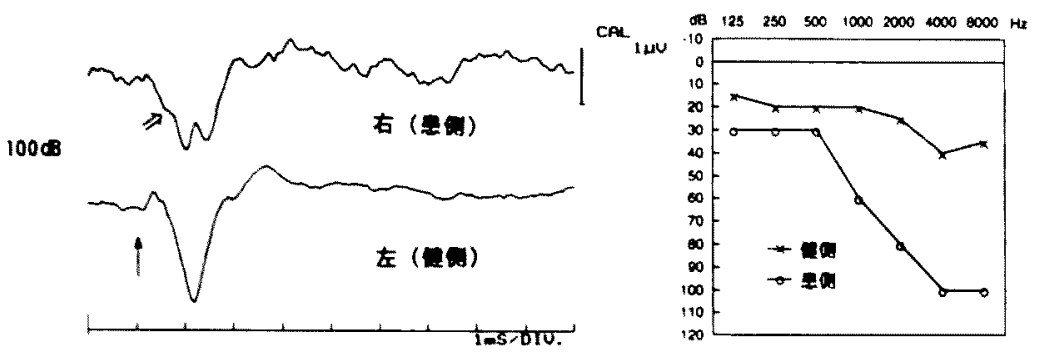

图 7 症例 30 螖量図原波形上オージオダラム

SP AP 比は $100 \mathrm{~dB}$ pe SPL て㭧側が0.50，健側が0.08. $\Rightarrow は$

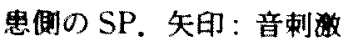

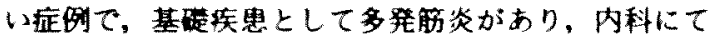

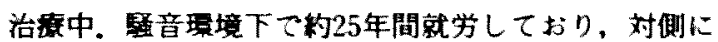

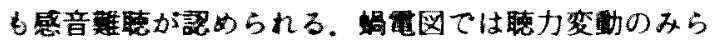
几た患側(右)のSPAP比が0.59上堌大しており，対 㑡 (左) OSP/AP比洁0.11で正常筑用内であった。

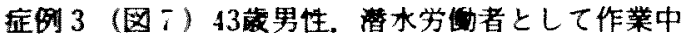
の、王変化に起因すると考えられた右外りンバ福症例.

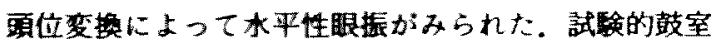

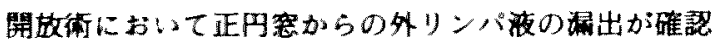

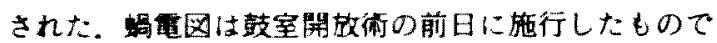

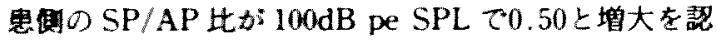

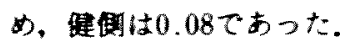

\section{考 粦}

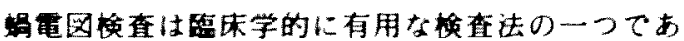

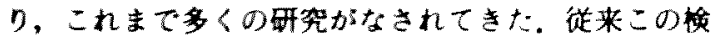

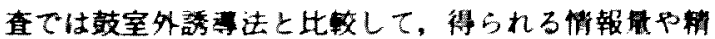

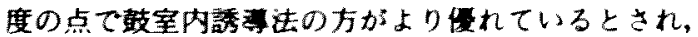
本邦では監床的には後者が主流"213*9であったたた

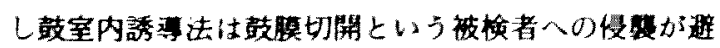
けられず，またそのたるに経過を迫って練り返し模直

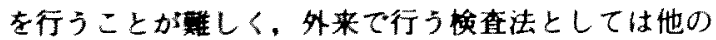
㳳党梌查に比较して普及しなかった面もある。これに

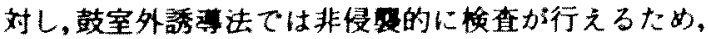
同一人物に対し短期間に数回の检直できるなどの利点

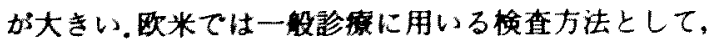

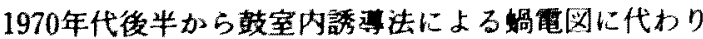

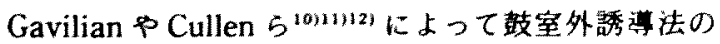
研究がはじまったささらに1980年㑯からSinghらによ

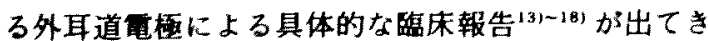
た。特にアメリカで优年侾室外誘速法が広く用いら れ，その有用性についての報告 ${ }^{19222)}$ も少なくない。こ
れらの報告の多くは、内リンバ水䏸にお゙いて SP/AP

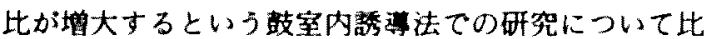
较・㛟討を行ったものてある，来際に行われている手

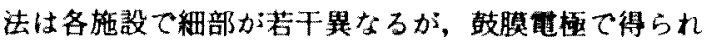

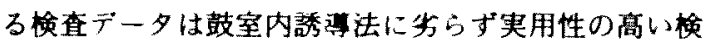
查法とさ扎ている ${ }^{622)}$. 鼓空外誘耑法てあれば耳喵 喉科医師てなくとも audiologist単独ても検查が可能 てあって，外来にて椱数の慗者の检㚗が出来るため， 鼓室外誘導法が広く普及している 231 と推察される. 我々も多数の患者にたいして侵裂の少ない䊑雨図検查 を行うことを第一目的とし，鼓膜㿠西图法の奏用性に ついての検討を試みたしのである。

今回創案した電極の特徽は，鼓膜に接する部分を使

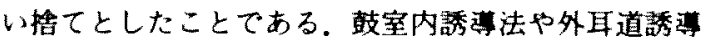

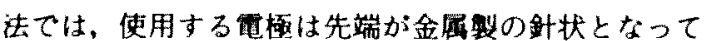
いたり，ボール状の先端がも出しになっているもの

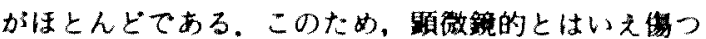

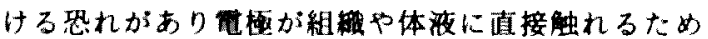
に，斶合によっては照桇の危险が生じる恐れもある。 これを防くには，一つの榙直が終わるたびに電棈を消

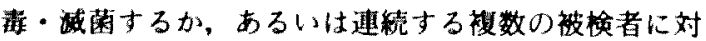
して器って再使用しないように多数の㧘極を用意する 必要がある。しかし金属の腐食による先端部分の务化 や，消毒過程における重植その6のの物理的椇鹪など が起きやすく，かかるコストや手間が負担になってく る.これに対して，我々の罡極ては組織に触れるのは 線花の部分と途中のシリコンチューブのみであり，一

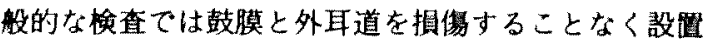
されるために，感染源となる可能性は非常に低い、し

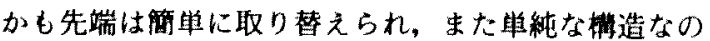
で消数も容にできるというメリットがある，また醀 堙にわずかてい分化がみられた埸合にチューブこと破 
雍して常に新しいものを使うように多数隼借しても， 搆造が単純で1個ちたりのコストが小さいため経济的

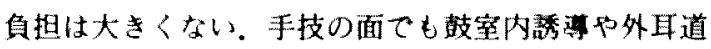

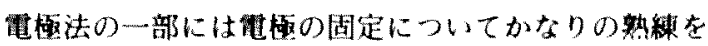
要するものもらるが, 我々の方法ていか心り简便化さ

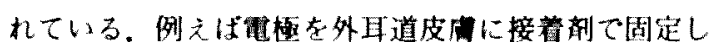

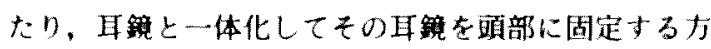

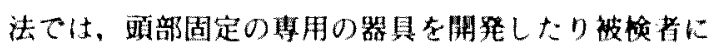

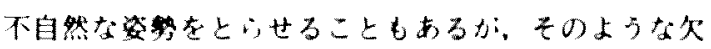
点はかなり解消されていると思れれる。目内に入れた

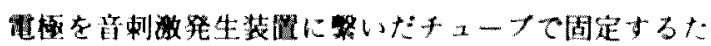

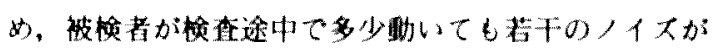

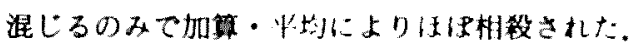

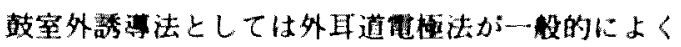

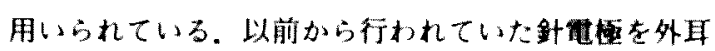

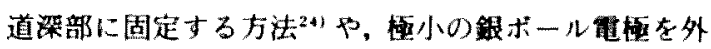

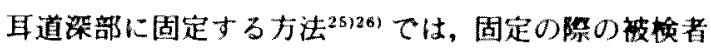
の终痛や，ちるいは借極が湘定中に移動し，それに伴っ

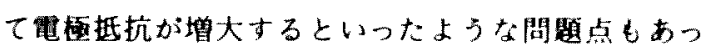

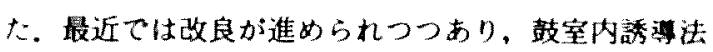
と避色ない成績を得大報告 ${ }^{2728}$ が見らんている。我々 が行った模徱ては，一般的な跂膜麻醇のみでは外耳道

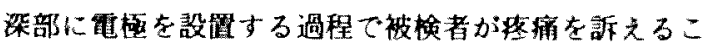
とがあり,こういつた新しい方法でし完全な在保除去

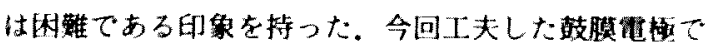
は，先端が臬らかい綿花であるためと思机るが，脚

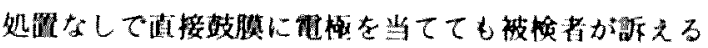

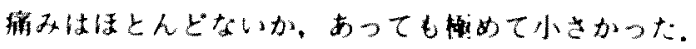
このため学生ボランティアなどを刘象とした武行段陆

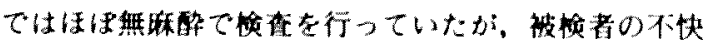

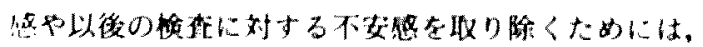

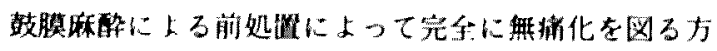

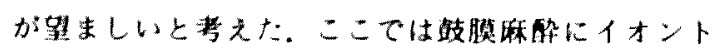

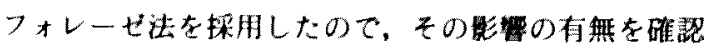
した。結果として跂䐎麻酔は反波形に影を及はさ ないことが明らかになったため，让常咥力例に刘する

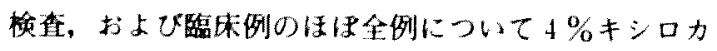
インとエビネフリンの溜台波によるイオン漫透法を用

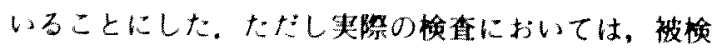

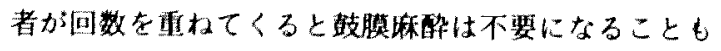
少なからず経䀧している。

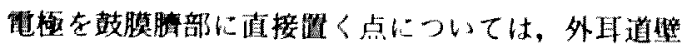

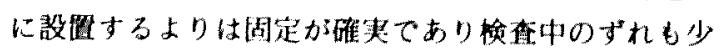

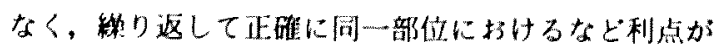

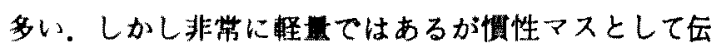
竟系に対して影霂があり，反応波形が何らかの修笁を

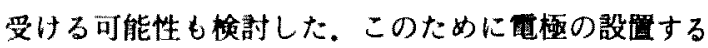
位裂を变えてそれそれ測定したが，結果からは外耳道 電極の波形と鼓㯖配梅て得られた波形ては，振幅に若

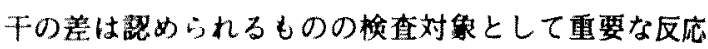
のバターンに差がなく，潜時についても差のない結果

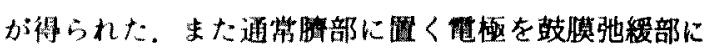
四くことも研みたが，AP，SPいずれも差がなく，固 它の面ては前者の方が镸れていており，この点につい ては先端の䋨花部分あるいは銀線を包んだシリコン

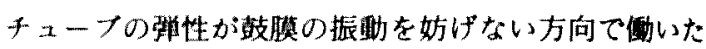

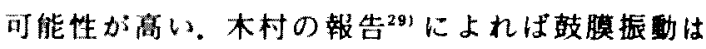
$1 \mathrm{kHz}$ 以下ては全体として捡的し，4kHz 以上ては分割

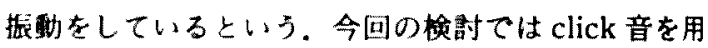
いており、ちょうど跂膜の共振周波数付近に相当する ことになるが、この周波数頒域の剌激音では浻部で 周辺部でし椺いが数められなかった。ただ例えばもっ と低い周波数を用いたburst 音などの剌湤では蚑俱の

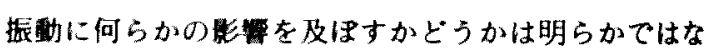
い.この点については今後応用筙囲を広げていく上て

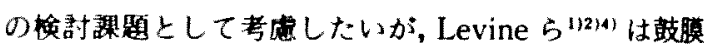
政極老用いてのburst 音での仾究も行っており, 従来

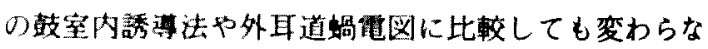
いデータが得られたよ報告している。

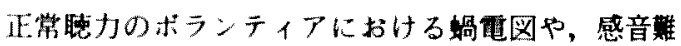

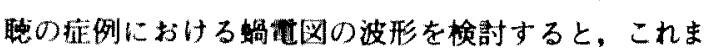

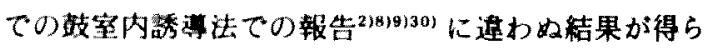

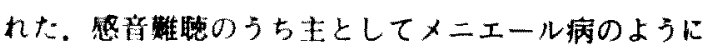
内リンパ水脂をその病照とする疾患てはSP/AP比が 均大るることか以前より報告313233) されている。本邦

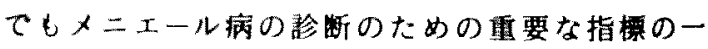

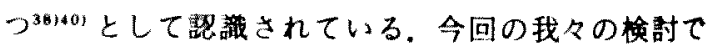

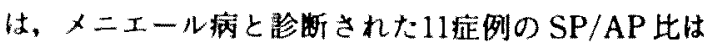
让需聴力者の平均值と比較して有意に大きく，使い搭

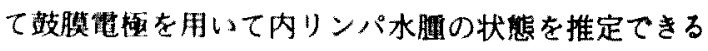
ことが示暖された．SP/AP比については，取近では

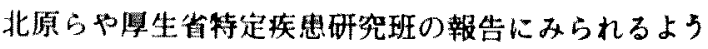
に0.37〜0.40以上を内リンパ水肠䧄性とする見

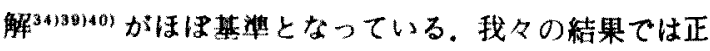
常例の SP/AP比の最大值は0.36です，平均值と㯲

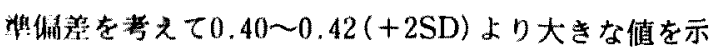

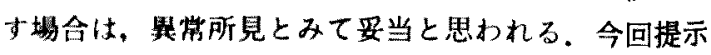

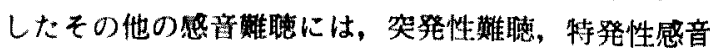




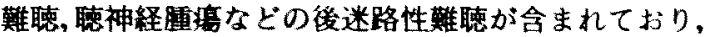
この群と正常咕力者ダループの SP/AP比には有意差 がなかった。しかしメニエール病のすへてにおいて SP/AP比の增大が壳められないのと同様に、これら の個々の疾患群についてもさらに群細な検郡を行っ て，鼓膜㧹电図て得られるテー夕をフィードバックす る必要があると思われた。また SP/AP比を测定する

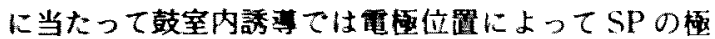
牲が变わることがあるか，一方鼓室外誘重ては安定し て、一SPが出現するとの赫告 ${ }^{301}$ がある。特にメ二エー

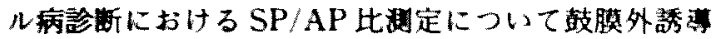

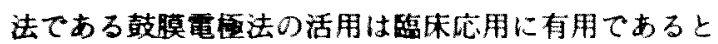
の昛象を持った。

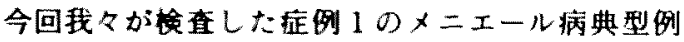

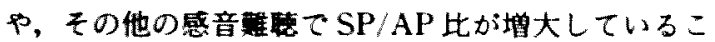

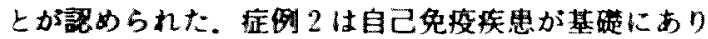

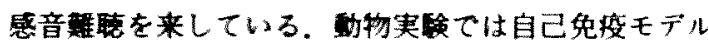

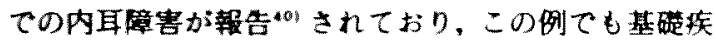

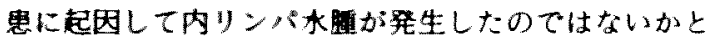

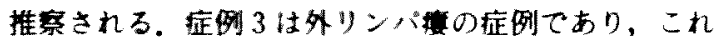

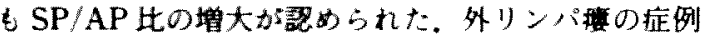
においては外りンバ破が染出することによって，相对

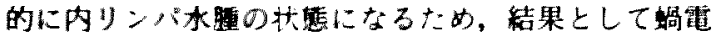

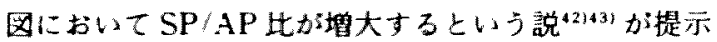

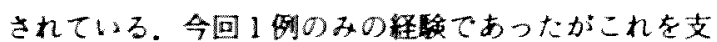

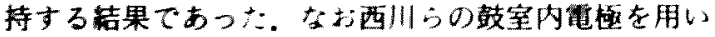
た報告に上んは，51列の模討で健側耳 SP/AP比が 0.40 以与のも0が 6 耳 $14 \%$ ，0.35以上は 10 耳 $23 \%$ に証 かられている。この報告てはメ二エール病怔例の健側

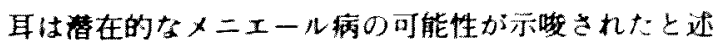

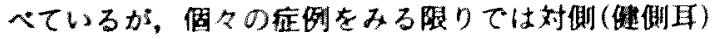
との比较有用住が离いと思っれる。

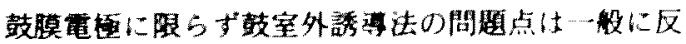
它電位が低いことで，条件にもよるが例えば䖝ボール

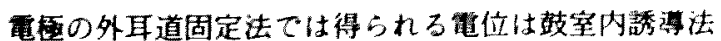

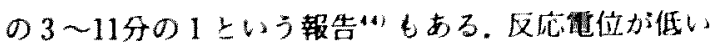

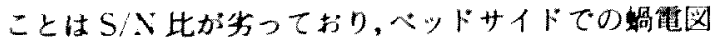

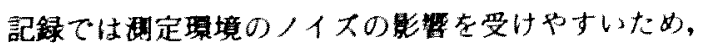
アースの設置やフィルタの設定には即煌が必要であ ろ. 正常㯖力ボランティアについては比較的小さな音 正でも良好な波形を得られたが，雖聴症例によっては 90 100dB peSPL でなと健側との比較が困難なも のもあった：しかし今回主として AP (N1) に主眼を おいて梌查した結果は满足すへきもので，従来より内
リンパ水膘の指標とされるーSP/AP 振幅比について も十分な情報が得られた。

鼓膜蝸電图法は婜者に対する険查前後のケアも十分 な説明さえ行えば特別なものは不要て，埥断に係わる 判定を除けば検㚗手技の修得やその翼就もさして困難 てはない，さらに疾患の程度を把提するのに，基準上 する正常聼力者のデータとの比较ばかりてなく，同一 人物の健常側の检直を行って臨休経過を追いながら， 随時波形を比㜞することも十分可能てあるう。小昛に

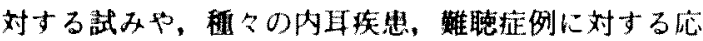
用・解析についてはまだ娭㣙すべ要素を残している

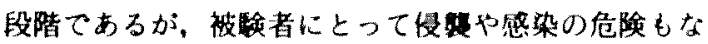

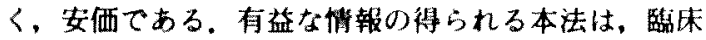
的に亟力て有用な内耳機能情法てはないかと考え Ђ.

\section{まとめ}

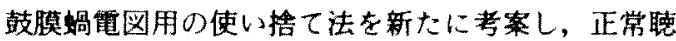
力者ならびに感音蜼聴症例についてその有用性，実用 性を㛟郡した。

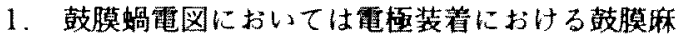

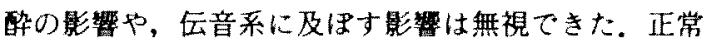
聴力者においては良好な AP 入出力曲線が得られ，㩆 室内誘導法に出らぬ結果であった。

2. 感音難聴症例で従来の力法に分ら梢報が得ら 几、また波形の比較を正常㯰力者のデータのみならず，

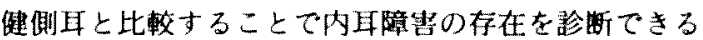
可能性が示惨された。

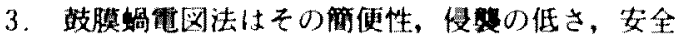

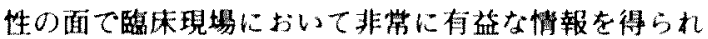
る手段となると考えられた。

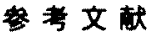

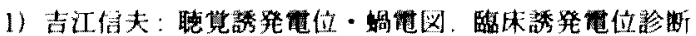

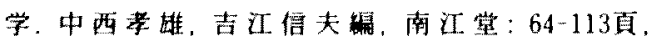
1989.

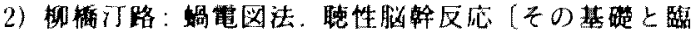
床了。鉿木䇻郎他編、メジカルビュー社：327-333 而, 1985

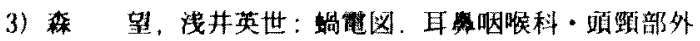
科Mook7，x二工一ル病とその閏辺疾想，金原出版 80-85 1988 .

4) Levine SC, Margolis RH, Fournier EM, Winzenburg SM : Tympanic electrocochleography for evalua. tion of endolymphatic hydrops. Laryngoscope 102 
$614-622,1992$.

5) Margolis RH, Levine SC, Fournier EM. Hunter LL. Smith SL, et al: Tympanic electrocochleography: normal and abnormal pattern of response. Audiology $31: 8-24,1992$.

6) Ruth RA : Trends in Electrocochleography. J Am Acad Audiol 1: 134 137, 1990.

7) Margolis RH. Rieks D, Fournier EMI. Levine SC: Tympanic electrocochleography for diagnosis of Meniere's Disease. Arch Otolaryngol Head Neck Surg 121: 45-55, 1995.

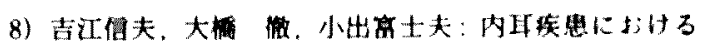

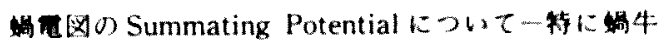

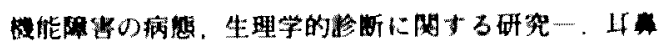
26: $143-163,1980$.

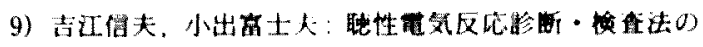

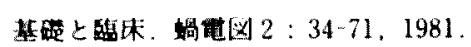

10) Coats AC: On Electrocochleographic electrode design. J Acoustic Soc Am 56: 708-711, 1974.

11) Gavilan C. Sanjuan J: Microphonic picked up from the human tympanic membrane. Ann Otol Rhinol Laryngol $76: 427-435,1976$.

12) Cullen JK Jr, Ellis MS, Berlin CI, Lousteau RJ: Human acoustic nerve action potential recordings from the tympanic membrane without anesthesia. Acta Otolaryngol (Stockh) 74: 15-22, 1972.

13) Singh CB, Mason SM, Brown PM : Extra-tympanic electrocochleography in clinical use. Evoked Poten. tial $41: 357-366,1980$.

14) Ferraro J, Murphy G. Ruth R: A comparative study of primary electrodes used in extratympanic electrocochleography. Semin Hear $i: 279 m 287$. 1986.

15) Coats AC: Electrocochleography: recording tech. niques and clinical applications. Semin Hear 7 : $247 \cdots 266,1986$.

16) Ruth R, Mills J, Ferraro J: Use of disposable ear canal electrodes in auditory brainstem response testing. Am J Otol 9: 310-315, 1988.

17) Lambert $P$, Ruth $R$ : Simultaneous recording of noninvasive ECoG and $\mathrm{ABR}$ for use in intraoperative monitoring. Otolaryngol Head Neck Surg 98 : $575-580,1988$.

18) Ruth R, Lambert P, Ferraro J : Electrocochleography: methods and clinical applications. Am J Otol Suppl 9 : 1-11, 1988.

19) Stypulkowski PH, Staller SJ : Clinical evaluation of a new ECoG recording electrode. Ear-Hear 8: 304-310, 1987.

20) Lilly Dj, Black FO: Electrocochleography in the diagnosis of Meniere's disease; in Nadol JB (ed) : Meniere's Disease. Berkeley, Kugler \& Ghedini, Calif.: pp 369-373, 1989.

21) Ferraro JA, Nunens RR, Arenberg IK: Tympanic EcochG and conventional ABR. Ear-Hear 10:161$166,1989$.

22) Ruth RA, Lambert P: Comparison of Tympanic membrane to promontory electrode recordings of electrocochleographic responses in patients with Meniere's disease. Otolaryngol Head Surg 100 : $546-552,1989$.

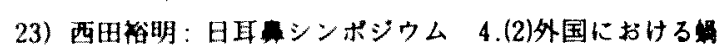

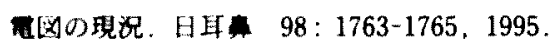

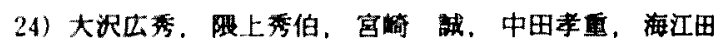

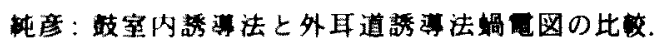
Audiology Japan 31: 17-23, 1988.

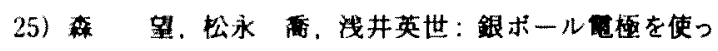

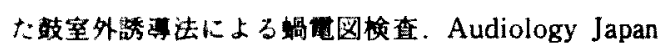
$21: 653-659,1978$.

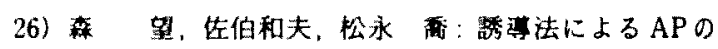
瑟について. Audiology Japan 23：451-452, 1980.

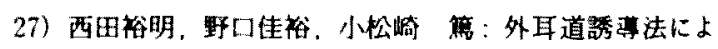

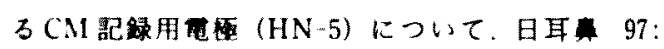
$1613=1620,1994$.

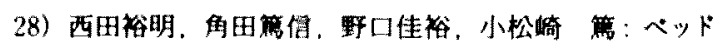
サイトてとれる略特マイクロホン再位 (CM) -イヤホ

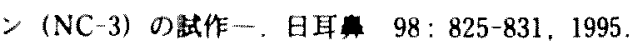

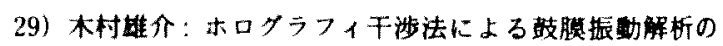

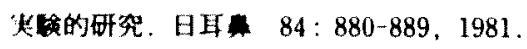

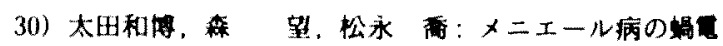

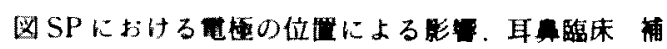
$37: 92-97,1990$.

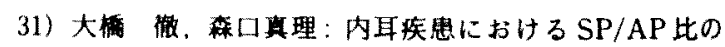

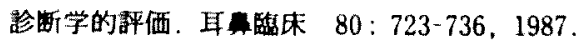

32）麻生 伸： $x$ 二エール病に対する臨床调百図の研究. 日耳烈 $93: 1093-1105,1990$.

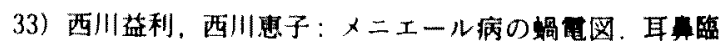
休 $87: 45^{-49}, 1994$

34) Coats $\mathrm{AC}$ : The summating potential and Meniere's disease: I, Summating potential amplitude in Meniere and non-meniere ears. Arch Otolaryngol 107: 107-208, 1981.

35) Portmann M, Aran JM : Electro-cochleography, Laryngoscope $81: 889-910,1971$. 
36) Yoshie N: Diagnostic significance of the electrocochleogram in clinical auditometry. Audiol 12 : 504 539, 1973.

37) Eggermont JJ, Odenthal DW : Action potentials and summating potentials in the normal human cochlea. Acta Otolaryngol Supple 316: 39-61, 1974.

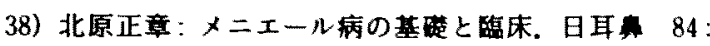
1353-1361, 1981 .

39）北原正年：次括却告。里生省特定疾急前庭機能異 常語査理平成 2 年研究報告重，1-4頁，1991。

40）北奥惠之，松永离，害多野㿟夫，成尾一应，田村

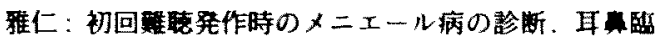
床 $86: 951-956.1993$.

41) Ohasi T, Tomoda K, Yoshie N : Electrocochleogra phic changes in endolymphatic hydrops induced by type Il collagen immunization through the stylomastoid foramen. Ann Otol Rhinol Laryngol 98 : 556-562, 1989.

42) Arenberg IK. Ackley RS. Ferraro J, Muchnik C:
ECoFG result in perilymphatic fistula : clinical and experimental studies. Otolaryngol Head Neck Surg $99: 435-443,1988$.

43) Campbell KCM, Savege MM, Harker LA : Electrocochleography in the presence of perilym. phatic fistula. Ann Otol Rhinol Laryngol 101 : 403407, 1992.

44) Humphries KN, Asccroft PB, Douek EE : Extratympanic electrocochleography. Acta Otolar. yngol. $83: 303-309,1977$.

本詥文の要旨の一部は第38回日本眝证医学会ならびに第 64回日耳富崎然地方部会にて口谓した。なお本研究は文

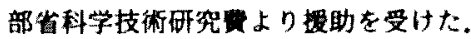

(1996年2月26日受䅻 1996年5月9日受理)

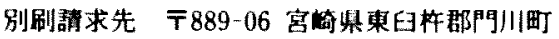
大字門川尾末 880 济生会日向病院耳咽喉科松溥宏司 


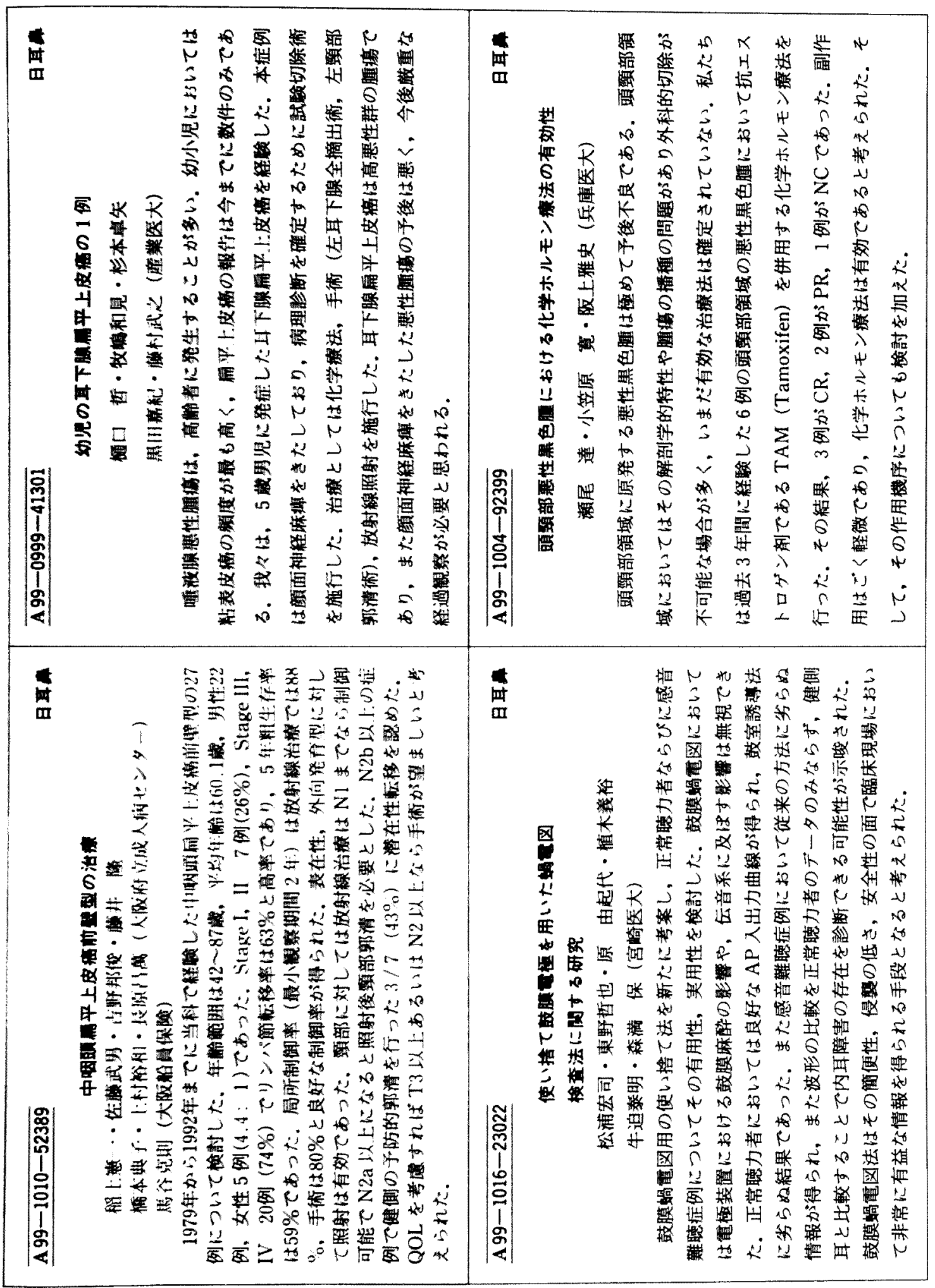

